\title{
Penerapan Sistem Hazard Analysis Critical Control Point (HACCP) pada Produk Banana Cake di Aerofood ACS Surabaya \\ Implementation of Hazard Analysis Critical Control Point (HACCP) on Banana Cake Product in Aerofood ACS Surabaya
}

Annisa Salsabila Setya Budi ${ }^{*}$, Trias Mahmudiono ${ }^{1}$

\begin{abstract}
ABSTRAK
Latar Belakang: Aerofood ACS Surabaya sebagai perusahaan jasa boga penerbangan bertaraf internasional diharuskan memiliki standar keamanan pangan yang baik untuk menjamin produk yang dihasilkan terhindar dari berbagai kontaminasi yang dapat menyebabkan foodborne disease. Sistem keamanan pangan yang diterapkan oleh Aerofood ACS Surabaya adalah Hazard Analysis Critical Control Point (HACCP), termasuk pada produksi banana cake.

Tujuan: Tujuan dari penelitian ini adalah untuk mengidentifikasi penerapan sistem HACCP pada produk banana cake di Aerofood ACS Surabaya.

Metode: Metode dari penelitian ini adalah metode deskriptif kualitatif yang meliputi observasi lapangan, wawancara, dan analisis dengan cara membandingan kondisi penerapan HACCP di lapangan dengan dokumen rencana HACCP yang telah ditetapkan oleh Aerofood ACS Surabaya. Penelitian dilakukan pada Bulan Januari hingga Februari 2020.

Hasil: Terdapat 19 tahap produksi banana cake hingga produk dapat didistribusikan ke pesawat dan dapat dinikmati oleh konsumen, yaitu penerimaan telur, penerimaan buah pisang, penerimaan bahan baku kering (tepung, gula, baking soda, dan minyak), penyimpanan telur, penyimpanan buah pisang, penyimpanan bahan baku kering, pemecahan telur, penyediaan air, pengayakan tepung, penimbangan, mixing, baking, pendinginan, pembentukan, pengemasan, penyimpanan banana cake di chiller, penataan pada tray, penyimpanan pada holding room, dan delivery ke pesawat. Dari 19 tahap produksi banana cake, terdapat empat titik kritis yaitu penerimaan telur, penyimpanan telur, baking, dan penyimpanan banana cake di chiller. Kesimpulan: Kontaminasi fisik, kimia, dan biologi pada produk banana cake dapat dicegah dengan memperhatikan setiap langkah terutama titik kritis. Aerofood ACS Surabaya telah melaksanakan sistem HACCP dengan baik dan sesuai dengan rencana HACCP yang telah ditetapkan.
\end{abstract}

Kata Kunci: HACCP, Keamanan Pangan, Jasa Boga Penerbangan, Foodborne Disease

\section{ABSTRACT}

Background: Aerofood ACS Surabaya as an international inflight catering service is required to have good food safety standards to ensure the quality of the products. The food safety system implemented by Aerofood ACS Surabaya on all its product is Hazard Analysis Critical Control Point (HACCP), including the banana cake. HACCP needs to be applied to prevent the possibility of physical, chemical, and biological contamination on food product that can cause foodborne disease.

Objectives: The purpose of this research was to identify the application of HACCP system to banana cake in Aerofood ACS Surabaya.

Methods: The method of this research was a qualitative descriptive method which includes field observation, interviews, and analysis by comparing the application of HACCP in the field with HACCP plan document that has been established by Aerofood ACS Surabaya. This research was conducted on January to February 2020.

Results: There were 19 steps to produce banana cake until it could be distributed to airlines and can be consumed by consumers: receiving of eggs, receiving of banana, receiving of dry goods (flour, sugar, baking soda, and oil), eggs storage, banana storage, dry goods storage, egg cracking, water supply, flour sifting, weighing, mixing, baking, chilling, shaping, packaging, banana cake storage, setting in the tray, holding room, and delivery to plane. From 19 steps to produce banana cake, there are four critical control points: receiving of eggs, eggs storage, baking, and banana cake storage.

Conclusions: Physical, chemical, and biological contamination on banana cake could be prevented by paying attention to each steps, especially the critical control point. Aerofood ACS Surabaya has implemented the HACCP system properly and accordance with the established HACCP plan.

Keywords: HACCP, Food Safety, Airlines Catering Service, Foodborne Disease

C2021. Budi. Open access under CC BY - SA license.

Received: 08-10-2020, Accepted: 18-02-2021, Published online: 01-09-2021.

doi: 10.20473/amnt.v5i3.2021.211-222. Joinly Published by IAGIKMI \& Universitas Airlangga 
*Korespondensi:

Annisasalsa98@gmail.com

Annisa Salsabila Setya Budi

${ }^{1}$ Departemen Gizi Kesehatan, Fakultas Kesehatan Masyarakat, Universitas Airlangga

Jl. Mulyorejo Surabaya, Indonesia

Published by Universitas Airlangga and IAGIKMI

\section{PENDAHULUAN}

Transportasi udara merupakan jenis transportasi yang banyak diminati karena keunggulannya dalam kecepatan dan kenyamanan. Salah satu fasilitas yang menunjang kenyamanan pada transportasi udara adalah adanya pelayanan makanan yang diberikan kepada penumpang, terutama pada penerbangan dengan rute yang jauh. Pelayanan makanan pada transportasi udara disediakan oleh perusahaan jasaboga yang bekerjasama dengan maskapai. Berdasarkan Peraturan Menteri Kesehatan Republik Indonesia Nomor 1096 tahun 2011 Jasaboga yang melayani angkutan umum internasional dan pesawat udara termasuk kedalam jasaboga golongan $\mathrm{C}^{1}$.

Terdapat persyaratan yang harus dipenuhi perusahaan jasaboga agar mendapatkan izin untuk beroperasi, salah satunya adalah persyaratan mengenai higiene dan sanitasi ${ }^{1}$. Higiene dan sanitasi harus diterapkan dengan baik dan benar untuk menjaga mutu dan keamanan pangan hingga sampai ke tangan konsumen. Sangat penting bagi produsen untuk menjaga mutu dan keamanan pangan produk yang diproduksi agar aman untuk dikonsumsi dan tidak menimbulkan foodborne disease.

Foodborne disease merupakan penyakit yang disebabkan karena mengonsumsi makanan yang mengandung tiga agen penyebab penyakit yaitu agen patogen (bakteri, virus, dan parasit), agen kimia (racun dan logam), dan agen fisik (pecahan kaca dan tulang) ${ }^{2}$. Pada umumnya, foodborne disease memiliki gejala klinis berupa masalah pada pencernaan seperti diare atau sakit perut, mulai dari yang ringan hingga berat ${ }^{3}$. Foodborne disease dapat terjadi apabila higiene dan sanitasi pengolahan makanan buruk ${ }^{4}$. Pada tahun 2010, diperkirakan 500 juta pasien menderita foodborne disease dan $30 \%$ diantaranya adalah anak-anak, serta menyebabkan kematian pada lebih dari 1 juta orang ${ }^{5}$. Hingga saat ini, foodborne disease masih menjadi masalah serius kesehatan masyarakat yang terjadi diseluruh dunia ${ }^{6}$.

Foodborne disease dapat dicegah dengan menerapkan keamanan pangan serta penerapan higiene dan sanitasi yang baik ${ }^{7}$. Keamanan pangan merupakan kondisi dan upaya yang diperlukan untuk mencegah pangan dari kemungkinan cemaran biologis, kimia, dan benda lain yang dapat mengganggu, merugikan, dan membahayakan kesehatan manusia ${ }^{8}$. Salah satu sistem yang dapat diterapkan untuk menjamin keamanan pangan adalah hazard Analysis Critical Control Point (HACCP). HACCP merupakan sistem keamanan pangan yang berfokus pada pengendalian bahaya dengan melakukan monitoring terhadap setiap tindakan pengolahan makanan, terutama pada titik kritis dan akan dilakukan tindakan koreksi segera apabila terjadi penyimpangan ${ }^{9}$.

Sebagai perusahaan jasaboga penerbangan bertaraf internasional, Aerofood ACS Surabaya sangat ketat dalam menjaga mutu dan keamanan pangan. Hal itu dibuktikan dengan diterapkannya sistem keamanan pangan HACCP pada setiap menu yang diproduksi. HACCP diterapkan mulai dari tahap penerimaan bahan baku hingga produk pangan sampai ke tangan konsumen. Semua itu dilakukan agar keamanan pangan tetap terjaga sehingga aman untuk dikonsumsi oleh konsumen dan tidak menimbulkan foodborne disease.

Salah satu menu makanan yang diproduksi oleh Aerofood ACS Surabaya adalah banana cake. Banana cake merupakan salah satu menu yang disajikan untuk pesawat Saudi Arabia Airlines dengan rute penerbangan Surabaya - Jeddah. Banana cake adalah kue basah dengan bahan utama pisang. Pisang merupakan salah satu jenis buah yang memiliki masa simpan relatif pendek, sehingga harus dilakukan pengolahan dengan baik dan benar untuk menghasilkan produk yang bermutu dan aman dikonsumsi. Tujuan dari penelitian ini adalah untuk mengidentifikasi penerapan sistem HACCP pada produk banana cake di Aerofood ACS Surabaya. Hasil studi ini bermanfaat sebagai bahan rekomendasi perbaikan agar dapat meningkatkan performa penerapan sistem HACCP di Aerofood ACS Surabaya khususnya pada menu banana cake sehingga Aeofood ACS Surabaya dapat selalu memroduksi produk pangan yang berkualitas dan aman.

\section{METODE}

Penelitian ini dilakukan oleh peneliti pada Bulan Januari hingga Februari di Aerofood ACS Surabaya, tepatnya pada bagian kitchen (bakery). Metode penelitian yang digunakan dalam penelitian ini adalah metode deskriptif kualitatif, yaitu metode penelitian yang bertujuan untuk membuat deskripsi secara sistematis, faktual, dan akurat mengenai objek yang diselidiki ${ }^{10}$. Langkah-langkah yang dilakukan dalam penelitian ini adalah sebagai berikut: mengidentifikasi langkah-langkah produksi banana cake mulai dari penerimaan bahan baku hingga banana cake didistribusikan ke pesawat. Informasi mengenai langkah-langkah produksi banana cake didapatkan dengan cara wawancara kepada karyawan yang bertugas dan melakukan observasi secara langsung.

Mengidentifikasi rencana HACCP pada menu banana cake yang telah ditetapkan oleh Aerofood ACS Surabaya dengan cara wawancara kepada pihak Quality Control dan mempelajari dokumen HACCP. Kemudian melakukan observasi lapangan untuk mengetahui kondisi nyata pelaksanaan HACCP di lapangan. HACCP terdiri dari 12 tahap, yaitu penyusunan tim HACCP, deskripsi produk,

C 2021. Budi. Open access under CC BY - SA license.

Received: 08-10-2020, Accepted: 18-02-2021, Published online: 01-09-2021.

doi: 10.20473/amnt.v5i3.2021.211-222. Joinly Published by IAGIKMI \& Universitas Airlangga 
identifikasi penggunaan produk, penyusunan diagram alir, verifikasi diagram alir, analisis bahaya, penentuan titik kritis atau critical control point (CCP), penetapan batas kritis untuk setiap CCP, penetapan sistem pemantauan HACCP, penetapan tindakan koreksi untuk setiap CCP, penetapan tindakan verifikasi, melakukan dokumentasi dan pencatatan ${ }^{11}$

Analisis data dilakukan dengan cara membandingkan penerapan HACCP di lapangan dengan dokumen rencana HACCP yang telah ditetapkan oleh Aerofood ACS Surabaya. Hal tersebut dilakukan untuk melihat kesesuaian penerapan HACCP di lapangan dengan rencana HACCP yang telah dibuat.

\section{HASIL DAN PEMBAHASAN}

Aerofood ACS Surabaya adalah anak perusahaan Garuda Indonesia yang bergerak di bidang jasaboga penerbangan. Aerofood ACS Surabaya hingga kini telah melayani lebih dari 40 maskapai penerbangan, baik penerbangan domestik, penerbangan internasional, maupun penerbangan VVIP seperti Penerbangan Presiden dan Wakil Presiden Republik Indonesia. Berdasarkan Peraturan Menteri Kesehatan Republik Indonesia Nomor 1096 tahun 2011, Aerofood ACS Surabaya termasuk dalam perusahaan jasaboga golongan C. Agar mendapatkan izin beroperasi, perusahaan jasaboga golongan $\mathrm{C}$ harus memenuhi persyaratan yang telah ditetapkan, salah satunya adalah persyaratan mengenai higiene sanitasi. Higiene sanitasi yang baik merupakan upaya untuk mengendalikan faktor risiko terjadinya kontaminasi terhadap makanan, baik yang berasal dari bahan makanan, penjamah makanan, maupun tempat dan peralatan pengolahan makanan agar makanan aman dikonsumsi ${ }^{12}$.

Aerofood ACS Surabaya, dalam upaya menjaga higiene sanitasi dan keamanan pangan, telah menerapkan ISO 22000 - 2005, ISO 9001 - 2008, dan HACCP. Sistem keamanan pangan HACCP diterapkan pada semua menu makanan yang diproduksi oleh Aerofood ACS Surabaya. Salah satunya adalah menu banana cake. Banana cake merupakan menu yang disajikan untuk pesawat Saudi Arabia Airlines dengan rute penerbangan Surabaya - Jeddah.
Tahap Penerapan Hazard Analysis Critical Control Point (HACCP) Di Aerofood ACS Surabaya

Penerapan sistem HACCP dimulai dengan membentuk tim HACCP, membuat layout pabrik, membuat deskripsi produk, membuat deskripsi bahan baku, menyusun diagram alir, dan menyusun tabel rencana kerja jaminan mutu. Tabel rencana kerja jaminan mutu terdiri dari 6 prinsip HACCP yaitu analisis bahaya, penentuan titik kritis atau critical control point (CCP), penetapan batas kritis untuk setiap CCP, penetapan sistem pemantauan HACCP, penetapan tindakan koreksi untuk setiap CCP, dan penetapan tindakan verifikasi. Berikut merupakan hasil observasi dan wawancara penerapan HACCP pada menu banana cake di Aerofood ACS Surabaya:

\section{Pembentukan Tim Haccp}

Tim HACCP dibentuk untuk membangun sistem keamanan pangan di Aerofood ACS Surabaya, mulai dari perencanaan hingga penerapan di lapangan. Berdasarkan hasil wawancara kepada pihak Quality Control, tim HACCP di Aerofood ACS Surabaya terdiri dari 9 orang yang berasal dari departemen yang berbeda pada jalur mutu dan memiliki kompetensi dalam hal sistem HACCP. Departemen tersebut adalah Management Representative, General Manager, Quality Assurance, Production, Operation, Chief, Human Capital, House Keeping, dan Customer Service.

\section{Layout Pabrik Aerofood ACS Surabaya}

Area pabrik Aerofood ACS Surabaya terbagi menjadi dua lantai. Lantai 1 merupakan area produksi dan area transportasi, sedangkan lantai 2 merupakan tempat penyimpanan bahan baku, kantor manajemen, klinik, musholla, dan kantin karyawan. Layout pabrik Aerofood ACS Surabaya dapat dilihat pada gambar 1 dan gambar 2 . 


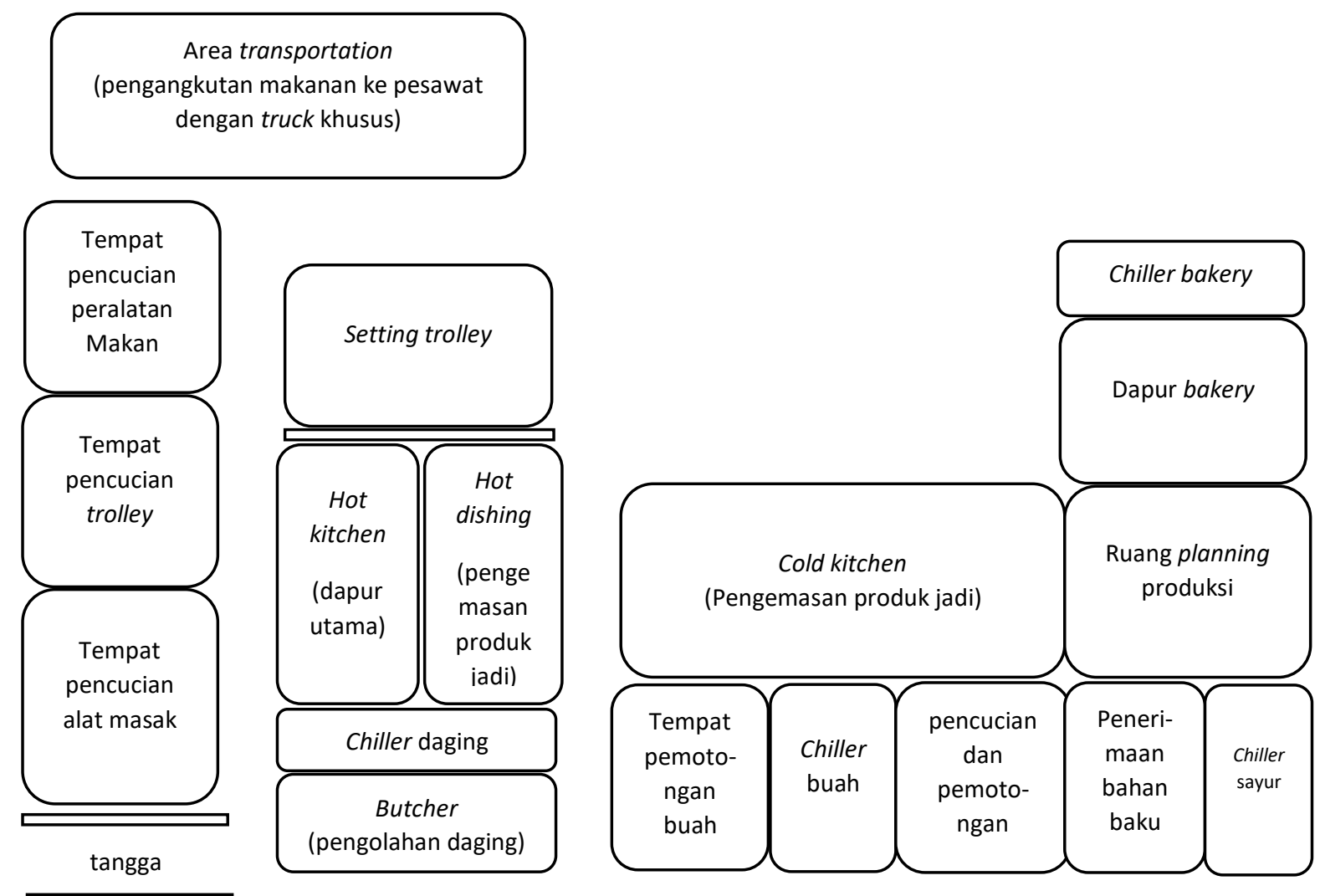

Gambar 1. Layout Pabrik Lantai 1

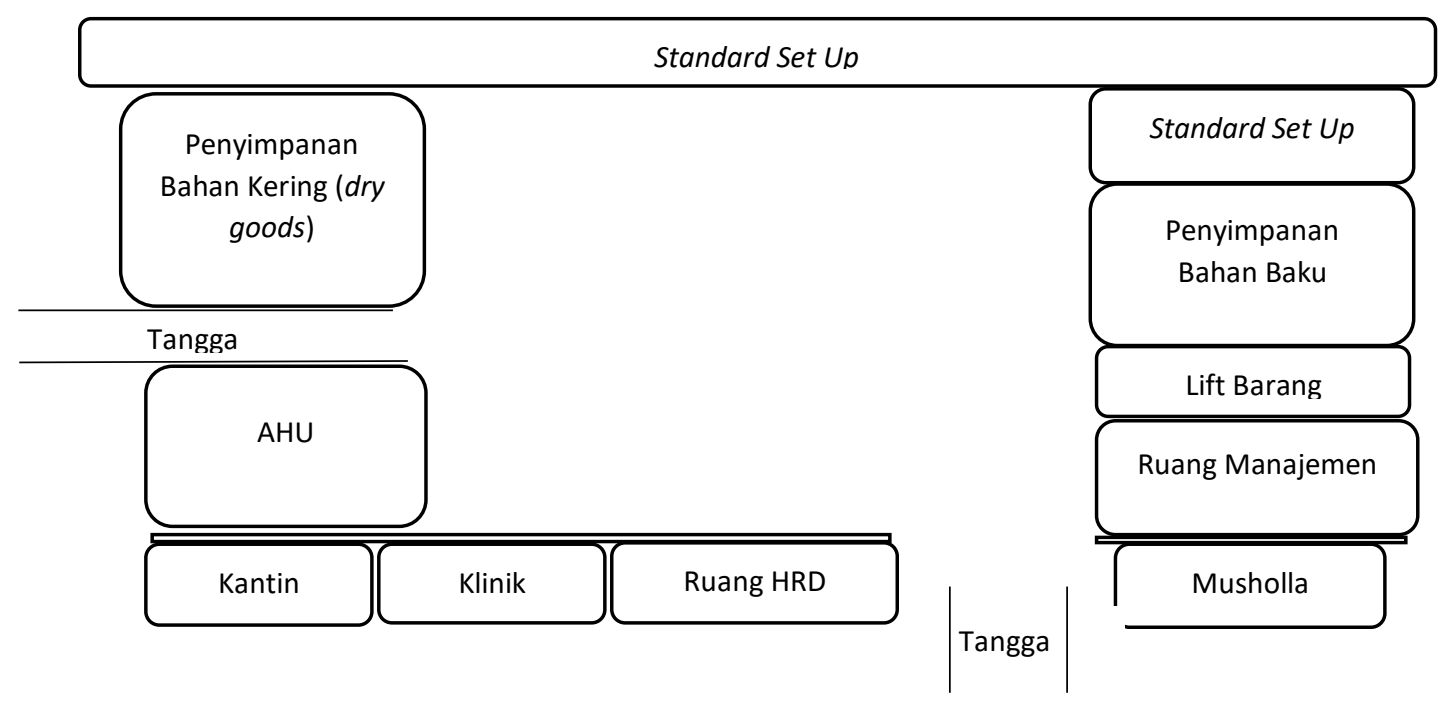

Gambar 2. Layout pabrik lantai 2

\section{Deskripsi Produk}

Banana cake merupakan kue dengan bahan utama pisang ambon yang disajikan sebagai makanan penutup pada pesawat Saudi Arabia Airlines kelas ekonomi dengan rute penerbangan Surabaya - Jeddaah. Berikut merupakan deskripsi produk banana cake secara lengkap yang diperoleh dari hasil wawancara kepada karyawan bagian produksi dan observasi secara langsung: Nama produk Banana Cake. Bahan baku pisang ambon, telur, tepung terigu protein tinggi, gula pasir, minyak, baking soda, air. Karakteristik produk warna kuning kecoklatan. Rasa manis. Berat 50 gram. Metode pengolahan pemanggangan dengan oven pada suhu 160 ${ }^{\circ} \mathrm{C}-170^{\circ} \mathrm{C}$ selama $30-40$ menit. Jenis Kemasan mangkuk plastik tebal berbentuk kubus dengan penutup bewarna bening. Kondisi penyimpanan pada chiller dengan suhu $0^{\circ} \mathrm{C}-5^{\circ} \mathrm{C}$. Masa simpan 3 hari setelah diproduksi. Metode distribusi dikirim ke pesawat dengan menggunakan truck

(C)2021. Budi. Open access under CC BY - SA license.

Received: 08-10-2020, Accepted: 18-02-2021, Published online: 01-09-2021.

doi: 10.20473/amnt.v5i3.2021.211-222. Joinly Published by IAGIKMI \& Universitas Airlangga 
khusus yang dilengkapi dengan pendingin. Identifikasi penggunaan konsumsi secara umum khususnya konsumsi untuk penumpang pesawat Saudi Arabia Airlines.

\section{Deskripsi Bahan Baku}

Banana cake dibuat dengan menggunakan bahan baku pilihan yang telah diseleksi sesuai dengan spesifikasi yang ditetapkan oleh perusahaan. Bahan baku yang sesuai dengan spesifikasi akan diterima dan segera disimpan di tempat penyimpanan sesuai dengan karakteristiknya agar kualitas bahan baku tetap terjaga. Spesifikasi bahan baku diperoleh dari hasil observasi dokumen spesifikasi bahan baku. Spesifikasi setiap bahan baku dapat dilihat pada tabel 1.

Tabel 1. Deskripsi Bahan Baku

\begin{tabular}{|c|c|c|}
\hline No & Jenis Bahan Baku & Spesifikasi Bahan Baku \\
\hline 1. & Pisang ambon & $\begin{array}{ll}\text { a. } & \text { Bewarna hijau } \\
\text { b. } & 3 / 4 \text { matang } \\
\text { c. } & \text { Tidak bonyok } \\
\text { d. } & \text { Segar } \\
\text { e. } & \text { Bersih } \\
\text { f. } & 1 \text { sisir berisi } 15-20 \text { buah }\end{array}$ \\
\hline 2. & Gula pasir & $\begin{array}{l}\text { a. Kemasan baik } \\
\text { b. Tanggal kaduluarsa minimal } 6 \text { bulan sebelum } \\
\text { c. Berat } 1 \text { sack: } 50 \mathrm{~kg}\end{array}$ \\
\hline 3. & Telur utuh & $\begin{array}{l}\text { a. Bersih, segar, tidak bocor } \\
\text { b. Warna : coklat tua } \\
\text { c. Berat : } 55-65 \mathrm{gr} / \text { butir } \\
\text { d. Panjang : } 5-6 \mathrm{~cm}\end{array}$ \\
\hline 4. & Tepung terigu protein tinggi & $\begin{array}{l}\text { a. Kemasan baik } \\
\text { b. Tanggal kadaluarsa minimal } 3 \text { bulan sebelum } \\
\text { c. Berat } 1 \text { sack : } 25 \mathrm{~kg}\end{array}$ \\
\hline 5. & Air & Sudah dilakukan klorinasi \\
\hline 6. & Minyak Sayur & $\begin{array}{l}\text { a. Kemasan baik, tidak kembung } \\
\text { b. Tanggal kadaluarsa minimal } 5 \text { bulan sebelum } \\
\text { c. Berat per kemasan: } 1 \mathrm{~L} \\
\text { d. Bewarna kuning cerah bening }\end{array}$ \\
\hline 7. & Baking soda & $\begin{array}{l}\text { a. Kemasan baik } \\
\text { b. Tanggal kadaluarsa minimal } 5 \text { bulan sebelum } \\
\text { c. Berat per kemasan: } 500 \mathrm{gr}\end{array}$ \\
\hline
\end{tabular}

\section{Penyusunan Diagram Alir}

Berdasarkan hasil wawancara kepada karyawan yang bertugas disertai dengan observasi secara langsung, diketahui bahwa proses produksi banana cake terdiri dari 19 langkah, dimulai dari penerimaan bahan baku hingga produk banana cake didistribusikan ke pesawat. Langkah pertama yang dilakukan dalam proses produksi banana cake adalah penerimaan bahan baku yang terdiri dari telur, pisang ambon, dan bahan baku kering (tepung, gula, baking soda, dan minyak). Bahan baku yang diterima adalah bahan baku yang telah melewati proses seleksi dan sesuai dengan spesifikasi yang telah ditetapkan. Selanjutnya, bahan baku akan disimpan di tempat penyimpanan sesuai dengan karakteristiknya. Langkah yang dilakukan pada proses pemasakan banana cake antara lain, pemecahan telur, penyediaan air, pengayakan tepung, penimbangan, mixing, baking, pendinginan, dan pembentukan. Banana cake yang telah dibentuk dengan cara dipotong sesuai dengan ukuran yang telah ditentukan kemudian dilakukan pengemasan, penyimpanan, penataan pada tray, penyimpanan pada holding room, dan delivery ke pesawat. Diagram alir proses produksi banana cake di Aerofood ACS Surabaya dapat dilihat pada gambar 3 . 


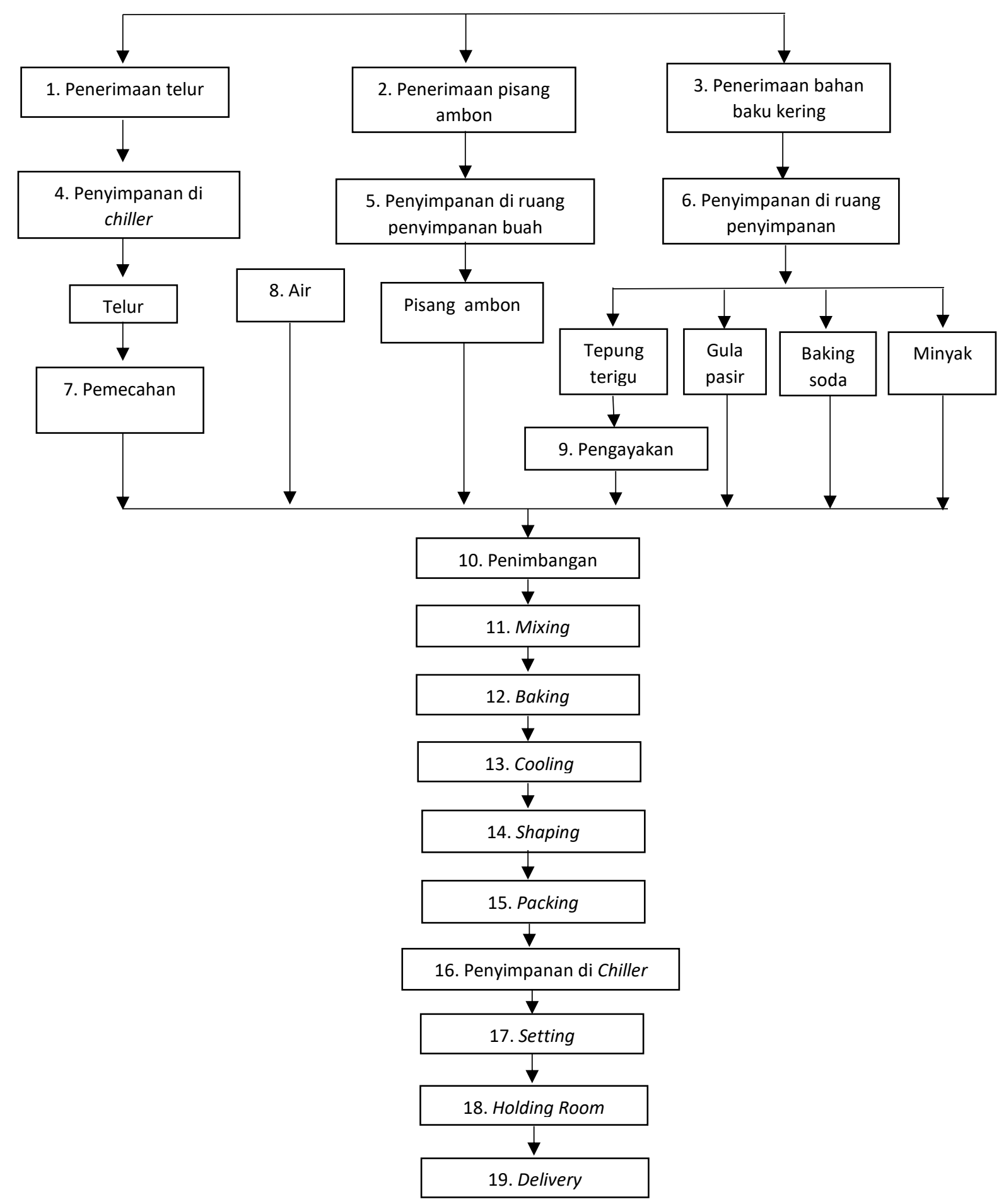

Gambar 3. Giagram Alir

\section{Prinsip 1: Identifikasi Bahaya}

Pada proses produksi banana cake, terdapat berbagai jenis bahaya yang dapat mengontaminasi produk, antara lain bahaya fisik, kimia, dan biologi. Identifikasi bahaya pada proses produksi banana cake dapat dilihat pada tabel 2 . 
Tabel 2. Identifikasi Bahaya

\begin{tabular}{|c|c|c|c|}
\hline \multirow{2}{*}{ Langkah } & \multicolumn{2}{|c|}{ Identifikasi Bahaya } & \multirow{2}{*}{ Sumber Bahaya } \\
\hline & F/K/B & Jenis & \\
\hline \multirow[t]{3}{*}{ Penerimaan telur } & $\mathrm{F}$ & $\begin{array}{l}\text { Batu, debu, kotoran } \\
\text { ayam }\end{array}$ & Terbawa dari pemasok \\
\hline & $\mathrm{K}$ & - & - \\
\hline & B & $\begin{array}{l}\text { Pertumbuhan mikroba } \\
\text { (Salmonella, Shigella, E. } \\
\text { Coli, Baciluscereus, } \\
\text { Staphilococcus aureus) }\end{array}$ & $\begin{array}{l}\text { Dari kotoran yang menempel pada cangkang } \\
\text { telur, transportasi saat pengiriman kurang } \\
\text { bersih }\end{array}$ \\
\hline \multirow[t]{3}{*}{ Penerimaan pisang ambon } & $\mathrm{F}$ & Debu, ulat & $\begin{array}{l}\text { Dari pemasok, transportasi saat pengiriman } \\
\text { kurang bersih }\end{array}$ \\
\hline & K & Pestisida & Dari pemasok \\
\hline & B & $\begin{array}{l}\text { Pertumbuhan mikroba } \\
\text { (Salmonella, Shigella, E. } \\
\text { Coli, Baciluscereus, } \\
\text { Staphilococcus aureus) }\end{array}$ & $\begin{array}{l}\text { Dari pemasok, transportasi saat pengiriman } \\
\text { kurang bersih }\end{array}$ \\
\hline \multirow{3}{*}{$\begin{array}{l}\text { Penerimaan bahan baku } \\
\text { kering (tepung terigu, gula } \\
\text { pasir, baking soda, dan } \\
\text { minyak) }\end{array}$} & $\mathrm{F}$ & Batu, debu, benda asing & Terbawa dari pemasok \\
\hline & K & - & - \\
\hline & B & Clostridium botulinum & Kemasan kurang higienis \\
\hline \multirow{3}{*}{$\begin{array}{l}\text { Penyimpanan telur di } \\
\text { chiller }\end{array}$} & $\mathrm{F}$ & - & - \\
\hline & K & - & - \\
\hline & B & $\begin{array}{l}\text { Pertumbuhan mikroba } \\
\text { (Salmonella, Shigella, E. } \\
\text { Coli, Baciluscereus, } \\
\text { Staphilococcus aureus) }\end{array}$ & Suhu chiller tidak sesuai, kontaminasi silang \\
\hline \multirow{3}{*}{$\begin{array}{l}\text { Penyimpanan pisang } \\
\text { ambon di ruang } \\
\text { penyimpanan buah }\end{array}$} & $\mathrm{F}$ & - & - \\
\hline & $\mathrm{K}$ & - & - \\
\hline & B & $\begin{array}{l}\text { Pertumbuhan mikroba } \\
\text { (Salmonella, Shigella, E. } \\
\text { Coli, Baciluscereus, } \\
\text { Staphilococcus aureus) }\end{array}$ & $\begin{array}{l}\text { Kontaminasi silang, kontaminasi pest dan } \\
\text { rodent }\end{array}$ \\
\hline \multirow{3}{*}{$\begin{array}{l}\text { Penyimpanan bahan baku } \\
\text { kering di ruang } \\
\text { penyimpanan }\end{array}$} & $\mathrm{F}$ & Benda asing & $\begin{array}{l}\text { Dari karyawan, peralatan, dan tempat } \\
\text { penyimpanan }\end{array}$ \\
\hline & K & Kontaminasi bahan kimia & $\begin{array}{l}\text { Kontaminasi silang dari bahan kimia non } \\
\text { foodgrade }\end{array}$ \\
\hline & B & $\begin{array}{l}\text { Pertumbuhan mikroba } \\
\text { (Salmonella, Shigella, E. } \\
\text { Coli, Baciluscereus, } \\
\text { Staphilococcus aureus) }\end{array}$ & Kontaminasi pest dan rodent \\
\hline \multirow[t]{3}{*}{ Pemecahan telur } & $\mathrm{F}$ & Pecahan cangkang telur & Proses pemecahan telur yang ceroboh \\
\hline & K & - & - \\
\hline & B & $\begin{array}{l}\text { Pertumbuhan mikroba } \\
\text { (Salmonella, Shigella, E. } \\
\text { Coli, Baciluscereus, } \\
\text { Staphilococcus aureus) }\end{array}$ & Terbawa dari cangkang yang kotor \\
\hline \multirow[t]{3}{*}{ Penyediaan air } & $\mathrm{F}$ & Benda asing & Dari peralatan, karyawan, dan lingkungan \\
\hline & $\mathrm{K}$ & - & - \\
\hline & B & $\begin{array}{l}\text { Pertumbuhan mikroba } \\
\text { (TPC, Coliform dan E. coli) }\end{array}$ & $\begin{array}{l}\text { Kualitas air kurang baik, dari peralatan, } \\
\text { karyawan, dan lingkungan }\end{array}$ \\
\hline \multirow[t]{3}{*}{ Pengayakan tepung terigu } & $\mathrm{F}$ & Kawat, benda asing & Ayakan yang rusak \\
\hline & K & - & - \\
\hline & B & $\begin{array}{l}\text { Pertumbuhan mikroba } \\
\text { amilolitik }\end{array}$ & Ayakan yang kotor \\
\hline
\end{tabular}




\begin{tabular}{|c|c|c|c|}
\hline \multirow{2}{*}{ Langkah } & \multicolumn{2}{|c|}{ Identifikasi Bahaya } & \multirow{2}{*}{ Sumber Bahaya } \\
\hline & F/K/B & Jenis & \\
\hline \multirow{3}{*}{ Penimbangan bahan baku } & $\mathrm{F}$ & Benda asing & Karyawan, timbangan kotor, dan lingkungan \\
\hline & $\mathrm{K}$ & - & - \\
\hline & $B$ & $\begin{array}{l}\text { Kontaminasi mikroba } \\
\text { (Salmonella, Shigella, E. } \\
\text { Coli, Baciluscereus, } \\
\text { Staphilococcus aureus) }\end{array}$ & $\begin{array}{l}\text { Kontaminasi silang, karyawan, dan timbangan } \\
\text { kotor }\end{array}$ \\
\hline \multirow[t]{3}{*}{ Mixing } & $\mathrm{F}$ & Benda asing & $\begin{array}{l}\text { Dari karyawan, peralatan yang kotor, dan } \\
\text { lingkungan }\end{array}$ \\
\hline & $\mathrm{K}$ & - & - \\
\hline & B & $\begin{array}{l}\text { Pertumbuhan mikroba } \\
\text { berspora }\end{array}$ & Alat yang kotor \\
\hline \multirow[t]{3}{*}{ Baking } & $\mathrm{F}$ & Benda asing & $\begin{array}{l}\text { Dari karyawan, peralatan yang kotor, dan } \\
\text { lingkungan }\end{array}$ \\
\hline & $\mathrm{K}$ & - & - \\
\hline & $\mathrm{B}$ & Pertumbuhan mikroba & Suhu baking tidak sesuai \\
\hline \multirow[t]{3}{*}{ Pendinginan } & $\mathrm{F}$ & Benda asing & $\begin{array}{l}\text { Dari karyawan, peralatan yang kotor, dan } \\
\text { lingkungan }\end{array}$ \\
\hline & $\mathrm{K}$ & - & - \\
\hline & $B$ & $\begin{array}{l}\text { Pertumbuhan mikroba } \\
\text { (Salmonella, Shigella, E. } \\
\text { Coli, Baciluscereus, } \\
\text { Staphilococcus aureus) }\end{array}$ & Suhu chiller tidak sesuai \\
\hline \multirow[t]{3}{*}{ Shaping } & $\mathrm{F}$ & Benda asing & Dari karyawan dan peralatan yang kotor \\
\hline & K & - & - \\
\hline & B & $\begin{array}{l}\text { Pertumbuhan mikroba } \\
\text { (Salmonella, Shigella, E. } \\
\text { Coli, Baciluscereus, } \\
\text { Staphilococcus aureus) }\end{array}$ & Dari karyawan dan peralatan yang kotor \\
\hline \multirow[t]{3}{*}{ Packing } & $\mathrm{F}$ & Benda asing & $\begin{array}{l}\text { Dari karyawan, peralatan yang kotor, dan } \\
\text { lingkungan }\end{array}$ \\
\hline & $\mathrm{K}$ & - & - \\
\hline & B & $\begin{array}{l}\text { Pertumbuhan mikroba } \\
\text { (Salmonella, Shigella, E. } \\
\text { Coli, Baciluscereus, } \\
\text { Staphilococcus aureus) }\end{array}$ & Kemasan kotor, dari karyawan \\
\hline \multirow[t]{3}{*}{ Penyimpanan di chiller } & $\mathrm{F}$ & - & - \\
\hline & $\mathrm{K}$ & - & - \\
\hline & B & $\begin{array}{l}\text { Pertumbuhan mikroba } \\
\text { (Salmonella, Shigella, E. } \\
\text { Coli, Baciluscereus, } \\
\text { Staphilococcus aureus) }\end{array}$ & Suhu chiller tidak sesuai \\
\hline \multirow[t]{3}{*}{ Setting pada trolley } & $\mathrm{F}$ & Benda asing & $\begin{array}{l}\text { Dari karyawan, peralatan yang kotor, } \\
\text { lingkungan akibat packaging yang kurang rapat }\end{array}$ \\
\hline & $\mathrm{K}$ & $\begin{array}{l}\text { Bahan kimia pembersih } \\
\text { (hand sanitizer dan } \\
\text { klorin) }\end{array}$ & Penempatan bahan sanitasi yang tidak tepat \\
\hline & $B$ & $\begin{array}{l}\text { Pertumbuhan mikroba } \\
\text { (Salmonella, Shigella, E. } \\
\text { Coli, Baciluscereus, } \\
\text { Staphilococcus aureus) }\end{array}$ & $\begin{array}{l}\text { Meningkatnya suhu produk selama setting, } \\
\text { Kontaminasi silang dari alat dan pekerja }\end{array}$ \\
\hline \multirow[t]{3}{*}{ Holding room } & $\mathrm{F}$ & - & - \\
\hline & $\mathrm{K}$ & - & - \\
\hline & B & $\begin{array}{l}\text { Pertumbuhan mikroba } \\
\text { (Salmonella, Shigella, E. } \\
\text { Coli, Baciluscereus, } \\
\text { Staphilococcus aureus) }\end{array}$ & Suhu penyimpanan yang tidak sesuai \\
\hline
\end{tabular}




\begin{tabular}{|c|c|c|c|}
\hline \multirow[t]{2}{*}{ Langkah } & \multicolumn{2}{|c|}{ Identifikasi Bahaya } & \multirow[t]{2}{*}{ Sumber Bahaya } \\
\hline & F/K/B & $\begin{array}{l}\text { Jenis } \\
\end{array}$ & \\
\hline \multirow[t]{3}{*}{ delivery } & $F$ & Benda asing & $\begin{array}{l}\text { Dari karyawan, peralatan yang kotor, dan } \\
\text { kendaraan yang kotor }\end{array}$ \\
\hline & $\mathrm{K}$ & - & - \\
\hline & B & $\begin{array}{l}\text { Pertumbuhan mikroba } \\
\text { (Salmonella, Shigella, E. } \\
\text { Coli, Baciluscereus) }\end{array}$ & $\begin{array}{l}\text { Kontaminasi silang dari kendaraan yang kotor } \\
\text { dan karyawan }\end{array}$ \\
\hline
\end{tabular}

\section{Prinsip 2: Penentuan Critical Control Point (CCP)}

Penentuan CCP dilakukan berdasarkan hasil analisa menggunakan diagram pohon keputusan. Terdapat empat CCP dalam proses produksi banana cake. Empat CCP tersebut meliputi penerimaan telur, penyimpanan telur di chiller, baking, dan penyimpanan banana cake di chiller.

\section{Penerimaan Telur}

Proses penerimaan telur merupakan langkah yang sangat penting dalam menentukan kualitas telur yang digunakan dalam pembuatan banana cake. Pada penerimaan telur, telur yang datang akan dicek kelayakannya dengan membandingkan kondisi telur dengan spesifikasi yang telah ditetapkan. Telur yang sesuai spesifikasi akan diterima sedangkan telur yang tidak sesuai spesifikasi ditolak.

Telur termasuk pada bahan baku yang memiliki risiko tinggi dapat menyebabkan foodborne disease. Hal tersebut dikarenakan telur menjadi tempat hidup yang ideal bagi beberapa bakteri, salah satunya Salmonella ${ }^{9}$. Oleh karena itu, Pada penerimaan telur, petugas quality control harus teliti dalam mengecek kondisi telur agar dapat mengurangi risiko digunakannya telur dengan kualitas yang kurang baik sehingga berisiko menimbulkan foodborne disease.

\section{Penyimpanan Telur di Chiller}

Telur yang sesuai dengan spesifikasi dan telah diterima kemudian disimpan dalam chiller dengan suhu $<$ $5^{\circ} \mathrm{C}$. Pada iklim tropis, telur mudah rusak jika tidak disimpan pada suhu yang tepat. Telur yang disimpan pada suhu ruang $\left(28^{\circ} \mathrm{C}-32^{\circ} \mathrm{C}\right)$ memiliki masa simpan sekitar 4 hari sejak ditelurkan. Namun, telur yang disimpan pada suhu $4^{\circ} \mathrm{C}$ akan memiliki masa simpan yang lebih lama, yaitu sekitar 3-4 minggu sejak ditelurkan ${ }^{13}$.

Suhu sangat penting dalam mempertahankan kualitas telur. Suhu $<5^{\circ} \mathrm{C}$ akan memperpanjang masa simpan telur karena dapat menghambat pertumbuhan bakteri Salmonella. Salmonella dapat hidup pada suhu $6,7^{\circ} \mathrm{C}-45^{\circ} \mathrm{C}$, sedangkan pada suhu dibawah $5^{\circ} \mathrm{C}$ Salmonella berhenti berkembang biak ${ }^{14}$. Suhu chiller dapat berubah dan tidak sesuai dengan yang telah ditetapkan apabila terjadi masalah pada mesin chiller. Hal tersebut dapat menyebabkan pertumbuhan mikroba pada telur, salah satunya Salmonella. Oleh karena itu, suhu chiller harus dipantau secara rutin.

\section{Baking (Pemanggangan)}

Baking merupakan proses pemanggangan banana cake dengan menggunakan oven. Banana cake merupakan produk yang mengandung telur sehingga proses baking harus dilakukan dengan suhu minimal $78^{\circ} \mathrm{C}$. Hal tersebut dikarenakan mikroba, termasuk bakteri pada telur, akan mati pada suhu $78^{\circ} \mathrm{C}^{15}$.

\section{Penyimpanan Banana Cake di Chiller}

Banana cake yang telah dikemas, selanjutnya akan disimpan dalam chiller dengan suhu $0^{\circ} \mathrm{C}-5^{\circ} \mathrm{C}$. Penyimpanan dalam chiller dilakukan sebelum banana cake di setting pada trolley yang akan dibawa ke pesawat. penyimpanan banana cake dilakukan di dalam chiller untuk mencegah terjadinya pertumbuhan mikroba pada banana cake.

\section{Prinsip 3: Penetapan Batas Kritis Setiap CCP}

Penetapan batas kritis pada setiap CCP dilakukan untuk menegah terjadinya kontaminasi fisik, kimia, dan biologi pada banana cake ${ }^{16}$. Batas kritis dari setiap CCP terdapat pada tabel 3. 
Tabel 3. Batas Kritis CCP Produk Banana Cake

\begin{tabular}{|c|c|c|c|c|c|}
\hline CCP & Bahaya & $\begin{array}{c}\text { Prinsip } 3 \\
\text { Batas Kritis }\end{array}$ & $\begin{array}{c}\text { Prinsip } 4 \\
\text { Pemantauan } \\
\text { What-where- } \\
\text { when-who-how }\end{array}$ & $\begin{array}{c}\text { Prinsip } 5 \\
\text { Koreksi dan } \\
\text { Tindakan Koreksi }\end{array}$ & $\begin{array}{c}\text { Prinsip } 6 \\
\text { Verifikasi }\end{array}$ \\
\hline $\begin{array}{l}\text { Penerimaan } \\
\text { Telur }\end{array}$ & $\begin{array}{l}\text { Debu, batu, kotoran } \\
\text { ayam, mikroba: } \\
\text { Salmonella, Shigella, } \\
\text { E. Coli, } \\
\text { Baciluscereus, } \\
\text { Staphilococcus } \\
\text { aureus }\end{array}$ & $\begin{array}{l}\text { Kondisi telur } \\
\text { sesuai spesifikasi } \\
\text { (Bersih, segar, } \\
\text { tidak bocor). }\end{array}$ & $\begin{array}{l}\text { Petugas quality } \\
\text { control } \\
\text { memeriksa } \\
\text { kondisi } \\
\text { organoleptik } \\
\text { telur yang } \\
\text { datang di area } \\
\text { penerimaan } \\
\text { barang. }\end{array}$ & $\begin{array}{l}\text { Telur yang tidak } \\
\text { sesuai spesifikasi } \\
\text { ditolak dengan } \\
\text { melampirkan } \\
\text { berita acara agar } \\
\text { dapat ditindak } \\
\text { lanjuti oleh } \\
\text { supplier. }\end{array}$ & $\begin{array}{l}\text { Memberi } \\
\text { teguran pada } \\
\text { supplier. }\end{array}$ \\
\hline $\begin{array}{l}\text { Penyimpanan } \\
\text { Telur di Chiller }\end{array}$ & $\begin{array}{l}\text { Pertumbuhan } \\
\text { mikroba } \\
\text { (Salmonella, } \\
\text { Shigella, E. Coli, } \\
\text { Baciluscereus, } \\
\text { Staphilococcus } \\
\text { aureus) }\end{array}$ & $\begin{array}{l}\text { Suhu chiller } 0^{\circ} \mathrm{C}- \\
5^{\circ} \mathrm{C} \text {, chiller bersih } \\
\text { tidak ada } \\
\text { kotoran. }\end{array}$ & $\begin{array}{l}\text { Petugas } \\
\text { engineering } \\
\text { memeriksa suhu } \\
\text { chiller setiap } 4 \\
\text { jam sekali } \\
\text { dengan melihat } \\
\text { suhu pada } \\
\text { display chiller. } \\
\text { Petugas } \\
\text { kebersihan } \\
\text { melakukan } \\
\text { pembersihan } \\
\text { chiller setiap } \\
\text { hari. }\end{array}$ & $\begin{array}{l}\text { Jika suhu chiller }> \\
5^{\circ} \mathrm{C} \text {, petugas } \\
\text { engineering akan } \\
\text { melakukan } \\
\text { pemeriksaan dan } \\
\text { perbaikan jika } \\
\text { diperlukan. } \\
\text { Jika suhu chiller } \geq \\
8^{\circ} \mathrm{C} \text {, telur } \\
\text { dipindahkan ke } \\
\text { chiller lain yang } \\
\text { suhunya sesuai } \\
\text { dan petugas } \\
\text { engineering } \\
\text { melakukan } \\
\text { pemeriksaan dan } \\
\text { perbaikan pada } \\
\text { chiller. }\end{array}$ & $\begin{array}{l}\text { Melaporkan } \\
\text { pada atasan } \\
\text { (general } \\
\text { manager dan } \\
\text { manager } \\
\text { engineering) dan } \\
\text { melakukan } \\
\text { kalibrasi alat }\end{array}$ \\
\hline Baking & $\begin{array}{l}\text { Benda asing dan } \\
\text { pertumbuhan } \\
\text { mikroba } \\
\text { (Salmonella, } \\
\text { Shigella, E. Coli, } \\
\text { Baciluscereus, } \\
\text { Staphilococcus } \\
\text { aureus) }\end{array}$ & $\begin{array}{l}\text { Suhu baking } \geq \\
78^{\circ} \mathrm{C} \text { karena } \\
\text { produk banana } \\
\text { cake } \\
\text { mengandung } \\
\text { telur. }\end{array}$ & $\begin{array}{l}\text { Chef mengatur } \\
\text { oven dengan } \\
\text { suhu } \geq 74^{\circ} \mathrm{C}\end{array}$ & $\begin{array}{l}\text { Bila temperatur } \\
\text { tidak memenuhi } \\
\text { standar,panggang } \\
\text { kembali hingga } \\
\text { temperatur } \\
\text { mencapai batas } \\
\text { kritis dan banana } \\
\text { cake matang. }\end{array}$ & $\begin{array}{l}\text { Melaporkan } \\
\text { pada atasan } \\
\text { (manager } \\
\text { engineering dan } \\
\text { general } \\
\text { manager) } \\
\text { apabila terjadi } \\
\text { masalah pada } \\
\text { suhu oven. }\end{array}$ \\
\hline $\begin{array}{l}\text { Penyimpanan } \\
\text { Banana Cake } \\
\text { di Chiller }\end{array}$ & $\begin{array}{l}\text { Pertumbuhan } \\
\text { mikroba } \\
\text { (Salmonella, } \\
\text { Shigella, E. Coli, } \\
\text { Baciluscereus, } \\
\text { Staphilococcus } \\
\text { aureus) }\end{array}$ & $\begin{array}{l}\text { Suhu chiller } 0^{\circ} \mathrm{C}- \\
5^{\circ} \mathrm{C}, \text {, chiller } \\
\text { bersih tidak ada } \\
\text { kotoran. }\end{array}$ & $\begin{array}{l}\text { Petugas } \\
\text { engineering } \\
\text { memeriksa suhu } \\
\text { chiller setiap } 4 \\
\text { jam sekali } \\
\text { dengan melihat } \\
\text { suhu pada } \\
\text { display chiller. } \\
\text { Petugas } \\
\text { kebersihan } \\
\text { melakukan } \\
\text { pembersihan } \\
\text { chiller setiap } \\
\text { hari. }\end{array}$ & $\begin{array}{l}\text { Jika suhu chiller > } \\
5^{\circ} \mathrm{C} \text {, petugas } \\
\text { engineering akan } \\
\text { melakukan } \\
\text { pemeriksaan dan } \\
\text { perbaikan jika } \\
\text { diperlukan. } \\
\text { Jika suhu chiller } \geq \\
8^{\circ} \mathrm{C}, \text { banana cake } \\
\text { dipindahkan ke } \\
\text { chiller lain yang } \\
\text { suhunya sesuai } \\
\text { dan petugas } \\
\text { engineering } \\
\text { melakukan } \\
\text { pemeriksaan dan } \\
\text { perbaikan pada } \\
\text { chiller. }\end{array}$ & $\begin{array}{l}\text { Melaporkan } \\
\text { pada atasan } \\
\text { (general } \\
\text { manager dan } \\
\text { manager } \\
\text { engineering) dan } \\
\text { melakukan } \\
\text { kalibrasi alat }\end{array}$ \\
\hline
\end{tabular}


Pada pelaksanaannya, Aerofood ACS Surabaya telah menjalankan HACCP dengan baik dan sesuai dengan rencana HACCP yang telah dibuat. Pada penerimaan telur, petugas quality control telah memilah dan hanya menerima telur sesuai dengan spesifikasi yang ditetapkan. Telur yang diterima segera dibawa ke chiller penyimpanan untuk disimpan. Suhu semua chiller yang ada di Aerofood ACS Surabaya, baik chiller penyimpanan bahan baku maupun chiller penyimpanan produk jadi, selalu dipantau dan dicatat oleh petugas engineering 4 jam sekali. Selain dilakukan pemantauan suhu secara rutin, chiller juga rutin dibersihkan. Petugas kebersihan akan melakukan pengecekan kebersihan chiller secara berkala setiap hari dan akan langsung melakukan pembersihan apabila ditemukan kotoran pada chiller. Hal tersebut dilakukan agar makanan dan bahan makanan yang disimpan dalam chiller tidak terkontaminasi oleh mikroba dan benda asing.

Banana cake merupakan produk yang mengandung telur sehingga proses baking harus dilakukan dengan suhu minimal $78^{\circ} \mathrm{C}$. Pada pelaksanaannya, proses baking yang dilakukan menggunakan suhu $160^{\circ} \mathrm{C}-170^{\circ} \mathrm{C}$ selama $30-40$ menit. Hal tersebut menunjukkan bahwa pelaksanaan baking telah sesuai dengan rencana HACCP yaitu dilakukan dengan suhu minimal $78^{\circ} \mathrm{C}$. Banana cake yang baru matang akan didinginkan terlebih dahulu sebelum dikemas. Pendinginan dilakukan di dalam chiller dengan meletakkan banana cake pada rak yang ditutup oleh plastik penutup, sehingga kontaminasi benda asing atau mikroba dapat dicegah. Semua karyawan Aerofood ACS Surabaya juga telah menggunakan alat pelindung diri (APD) pada saat menjamah makanan. APD yang digunakan antara lain hair cap, appron, sarung tangan latex atau plastik, sepatu tertutup, dan masker. Hal tersebut dilakukan untuk mencegah kontaminasi dari karyawan pada makanan yang diproduksi.

Setelah dingin, banana cake akan dipotong (shaping) dengan ukuran kurang lebih $5 \times 5 \mathrm{~cm}$ dan dikemas. Setelah dikemas, banana cake akan disimpan kembali pada chiller hingga banana cake akan disetting pada trolley. Banana cake tidak langsung disetting pada trolley karena proses setting dilakukan 12 jam sebelum produk makanan dikirim ke pesawat.

Proses setting dilakukan diruang terpisah dari ruang produksi, yaitu dilakukan di area setting. Setelah banana cake disetting pada trolley, trolley akan dimasukkan ke dalam holding room hingga tiba waktu pengiriman banana cake ke pesawat sesuai dengan jadwal keberangkatan pesawat. Pada pelaksanaannya, suhu holding room selalu dipantau agar suhunya tetap berada pada $0^{\circ} \mathrm{C}-5^{\circ} \mathrm{C}$. Trolley akan dikeluarkan dari holding room pada saat akan dikirim ke pesawat.

\section{KESIMPULAN}

Proses produksi banana cake memeliki tiga jenis potensi bahaya, yaitu bahaya fisika, kimia, dan biologi. Pengendalian dan pencegahan bahaya dilakukan Aerofood ACS Surabaya dengan menerapkan sistem keamanan pangan HACCP. Berdasarkan langkah produksi banana cake, mulai dari penerimaan bahan baku hingga pengiriman ke pesawat, terdapat empat langkah yang ditetapkan sebagai titik kritis atau CCP, yaitu penerimaan telur, penyimpanan telur, baking, dan penyimpanan banana cake di chiller. Pada pelaksanaannya, Aerofood ACS Surabaya telah melaksanakan sistem HACCP dengan baik dan sesuai dengan rencana HACCP yang telah ditetapkan. Aerofood ACS Surabaya sangat memperhatikan setiap tahap produksi, terutama pada tahap yang ditetapkan sebagai CCP agar berjalan dengan baik sesuai rencana HACCP.

\section{ACKNOWLEDGMENT}

Peneliti menyampaikan ucapan terima kasih kepada Aerofood ACS Surabaya yang telah memberikan kesempatan kepada peneliti untuk melakukan penelitian mengenai penerapan sistem HACCP pada produk banana cake. Peneliti juga menyampaikan terima kasih kepada Bapak Soedarwanto, S.E selaku dosen pembimbing lapangan, serta Ibu Lailatul Muniroh, S.KM., M.Kes selaku dosen pembimbing di Universitas Airlangga.

\section{REFERENSI}

1. Peraturan Menteri Kesehatan Republik Indonesia Nomor 1096/MENKES/PER/VI/2011 Tentang Higiene Sanitasi Jasaboga. (2011).

2. Todd, E. C. D., Michaels, B. S., Smith, D., Greig, J. D. \& Bartleson, C. A. Outbreaks Where Food Workers Have Been Implicated in the Spread of Foodborne Disease. Part 9. Washing and Drying of Hands to Reduce Microbial Contamination. J. Food Prot. 73, 1937-1955 (2010).

3. Debra, G. et al. Vital Signs: Incidence and Trends of Infection with Pathogens Transmitted Commonly Through Food - Foodborne Diseases Active Surveillance Network, 10 U.S. Sites, 19962010. Journal of Safety Research vol. 60 https://www.cdc.gov/mmwr/preview/mmwrht $\mathrm{ml} / \mathrm{mm} 6022 \mathrm{a} 5 . \mathrm{htm}$ (2011).

4. Institute of Medicine and National Research Council. Enhancing Food Safety: The Role of the Food and Drug Administration. Enhancing Food Safety (The National Academies Press, 2010). doi:10.17226/12892.

5. Kirk, M. D. et al. World Health Organization Estimates of the Global and Regional Disease Burden of 22 Foodborne Bacterial, Protozoal, and Viral Diseases, 2010: A Data Synthesis. PLoS Med. 12, 1-21 (2015).

6. Foodbrone Diseases. (Academic Press, 2018).

7. International Commission on Microbial Specifications for Foods. Sampling to Assess Control of the Environment. Microorganisms in Foods 7 (2018). doi:10.1007/978-3-319-684604_12.

8. Peraturan Pemerintah Republik Indonesia 
Nomor 86 Tahun 2019 Tentang Keamanan Pangan. Peratur. Pemerintah Tentang Keamanan Pangan 2019, 1-102 (2019).

9. Wallace, C. A., Sperber, W. H. \& Mortimore, S. E. Food Safety for the 21st Century (Managing HACCP and Food Safety Throughout the Global Supply Chain). (Wiley, 2018).

10. Arikunto, S. Prosedur Penelitian: Suatu Pendekatan Praktik. (Rineka Cipta, 2011).

11. Martimore, S. \& Wallace, C. HACCP: A Practical Approach. (Springer, 2013).

12. Marriott, N. G., Schilling, W. \& Gravani, R. B. Principles of Food Sanitation. (Springer, 2018).

13. Peraturan Kepala Badan Pengawas Obat dan
Makanan Republik Indonesia Nomor 5 Tahun 2015 Tentang Pedoman Cara Ritel Pangan yang Baik di Pasar Tradisional. 1-30 (2015).

14. Ray, B. Fundamental Food Microbiology. (CRC Press LLC, 2005).

15. Pasue, S., Dali, F. A. \& Mile, L. Uji Salmonella sp . pada Yellowfin Tuna (Thunnus albacores) yang Dipasarkan di Kota Gorontalo 1 Riwan Jurusan Teknologi Hasil Perikanan, Fakultas Perikanan dan IImu Kelautan, Universitas Negeri Gorontalo. 4, (2016).

16. Surak, J. \& Wilson, S. The Certified HACCP Auditor Handbook. (2014). 